Jurnal Komunikatio Volume 4 Nomor 1, April 2018

\title{
PENGARUH MENONTON TAYANGAN FTV KUASA ILAHI TERHADAP PERILAKU MASYARAKAT
}

\section{THE INFLUENCE OF WATCHING FTV OF KUASA ILAHI AGAINST PEOPLE'S BEHAVIOR}

\author{
Utri Indah Lestari $^{1 \mathrm{a}}$, Undang Suryatna ${ }^{2}$, AA Kusumadinata ${ }^{3 \mathrm{a}}$ \\ Ps. Ilmu Komunikasi, Fakultas Ilmu Sosial Dan Ilmu Politik, Universitas Djuanda Bogor, \\ Jl. Tol No 1 Kotak Pos 35 Bogor 16740 \\ "Korespondensi: UI Lestari, Email: utriindahlestari19@gmail.com \\ AA Kusumadinata, Email: alialamsyahkusumadinata@gmail.com
}

(Diterima: 26-03-2018; Ditelaah: 04-04-2018 ; Disetujui: 08-04-2018 )

\begin{abstract}
ABSTRAK
Penelitian ini memfokuskan bahwa dengan menonton tayangan FTV Kuasa Ilahi dapat merubah perilaku masyarakat. Dengan adanya tayangan tersebut masyarakat akan mengetahui hal apa saja yang boleh dilakukan dan tidak boleh dilakukan sesuai dengan syariat Islam, yang membuat masyarakat lebih intropeksi terhadap diri sendiri dan akan menjadi umat yang lebih taat kepada Tuhan-Nya. Penelitian ini bertujuan untuk (1) menganalisis karakteristik masyarakat terhadap tayangan FTV Kuasa Ilahi dan konten tayangan FTV Kuasa Ilahi, (2) Mengetahui pengaruh tayangan FTV kuasa ilahi terhadap perilaku menonton. Penelitian ini menggunakan metode penelitian kuantitatif. Hasil penelitian yang dilakukan menggunakan deskriptif menunjukan bahwa (1) karakteristik masyarakat yang menonton tayangan FTV pada kategori usia remaja dewasa, dengan pendidikan mayoritas bertaraf SMA dan frekuensi menonton menunjukan kategori sering. Sedangkan kategori konten film, alur cerita, karakter penokohan dan nilai budaya menunjukan keterpaan yang intensif dari penonton. (2) Terdapat hubungan yang kuat antara perilaku menonton tayangan FTVdengan konten tayangan.
\end{abstract}

Kata kunci : Perilaku Masyarakat, Tayangan FTV

\begin{abstract}
The study focuses on watching the divine power FTV display which could be change the behavior of society. With the show the public will know what can be done and should not be done in accordance with the Islamic law, which makes the society more introspective towards themselves and will become a people who was more loyal to God. This study aimed to (1) ) to knowed the characteristics of the public against the impressions of the FTV of Divine Power and the content of the FTV show of Divine Power, (2) to knowed the influence of the FTV show of divine power on the watch behavior. This research used quantitative research method. The result of the research used to descriptive indicates that (1) the characteristics of the people who watched the FTV showed in the adult teenage age category, with the majority of high school education and the frequency of watching shows the frequent category. While the categories of movie content, storyline, characterization and cultural values showed the intensive intentions of the audience. (2) There was a strong relationship between the viewing behavior of FTV impressions with the content of the impressions
\end{abstract}

Keywords : Community Behavior, FTV Impressions 
UI Lestari, U Suryatna, AA Kusumadinata. 2018. Pengaruh Menonton Tayangan FTV Kuasa Ilahi Terhadap Perilaku Masyarakat. Jurnal Komunikatio 4 (1) : 51-62. 


\section{PENDAHULUAN}

Menonton televisi adalah suatu tindakan yang tidak lepas dari dorongan masing-masing individu untuk menikmati apa yang ditayangkan oleh televisi. Dengan kata lain, tindakan menonton televisi adalah kesadaran seseorang terhadap sesuatu yang berhubungan dengan dorongan yang ada dalam diri individu sehingga seseorang memusatkan perhatiannya terhadap acara yang ditayangkan ditelevisi dengan senang hati, serta dengan perasaan puas sehingga pemirsa dapat menikmati apa yang ditayangkan oleh televisi tersebut.

Perkembangan siaran televisi di Indonesia, didahului oleh kuatnya posisi tayangan televisi sebagai media hiburan. Effendy (2003), televisi merupakan alat komunikasi yang mempunyai fungsi informasi, fungsi pendidikan, fungsi menghibur, fungsi mempengaruhi. Indonesia sendiri merupakan Negara yang mayoritasnya menganut agama Islam, jadi saat ini banyak stasiun televisi yang membuat sinetron religi, maksud dan tujuan dari acara tersebut yaitu untuk mengubah perilaku masyarakat agar tetap mengingat Allah SWT.

Seperti halnya stasiun televisi MNCTV, mereka membuat sinetron Kuasa Ilahi yang tayang setiap Senin sampai Jum'at pada pukul 22.00 sampai 22.45 WIB. Sinetron inipun sebagai salah satu acara unggulan yang bernuansa religius. Cerita dalam sinetron Kuasa Ilahi merupakan sesuai dengan situasi dan kondisi perilaku keagamaan masyarakat saat ini. Dari sinetron ini pun dapat dijadikan sebagai renungan di kalangan umat muslim.

\section{Kerangka Konsep}

\section{Televisi Sebagai Media Massa}

Effendy (2003) televisi adalah siaran yang merupakan media dari jaringan komunikasi dengan ciri-ciri yang dimiliki komunikasi massa, yaitu berlangsung satu arah, komunikatornya melembaga, pesannya bersifat umum, sasarannya menimbulkan
Walaupun sinetron religi kurang diminati oleh masyarakat tetapi ini merupakan sinetron yang mendidik atau edukatif dari dibidang keagamaan. Dari sinetron religi kita dapat menentukan mana yang baik dan buruk. Kita bisa melihat dilingkungan masyarakat mereka berperilaku tanpa tau sebab akibatnya. Contoh kasusnya yaitu seseorang bekerja yang tidak halal lalu ketika ia meninggal ia mendapatkan azab yang pedih hingga mayat nya pun menjadi berbau busuk. Dan disitu kita bisa lihat bahwa Kuasa Allah SWT itu memang sungguh benar nyata, penelitian sebelumnya yang dilakukan oleh Rinawati (2002) menunjukan televisi telah mampu menyihir para penonton yang menyaksikan adegan yang ada di dalam cerita, hal ini menjadi hiburan yang diminati masyarakat. Siaran televisi telah memberikan pengaruh yang sangat besar dalam kehidupan sehari-hari. Hal ini dapat dilihat dari banyaknya waktu yang digunakan untuk menonton televise (Desti 2005, Bahari et al. 2017).

Konsep dari tayangan religi adalah untuk merubah sikap atau perilaku masyarakat dan untuk lebih dekat sang pencipta yaitu Tuhan Yang Maha Esa pada tulisan ini peneliti ingin melihat FTV Kuasa Ilahi dalam perspektif penonton yang melihatnya. Tujuan penelitian ini adalah 1) menganalisis karakteristik masyarakat terhadap tayangan FTV Kuasa Ilahi dan konten tayangan FTV Kuasa Ilahi, (2) Mengetahui pengaruh tayangan FTV kuasa ilahi terhadap perilaku menonton. Penelitian ini menggunakan metode penelitian kuantitatif.

keserampakan, dan komunikasinya bersifat heterogen.Televisi adalah media yang mentransmisikan gambar dan suara. Desti (2005) televisi merupakan media yang paling efektif dan efisien dalam penyampaian pesanpesan atau ide-ide dari penyampai pesan, karena media televisi tidak hanya 
mengeluarkan suara saja tetapi juga disertai dengan gambar dan warna

Televisi sebagai salah satu sarana komunikasi massa memiliki ciri-ciri sebagai berikut Wahyudi (1996) ;

1. Informasi disampaikan kepada komunikan melalui proses perencanaan atau transmisi.

2. Isi pesan audiovisual artinya dapat didengar dan dilihat pada waktu bersamaan.

3. Sifatnya periodik atau tidak dapat diulang.

4. Sifatnya transmisi (artinya meneruskan), pesan-pesan yang diterima hanya dapat dilihat dan didengar secara sekilas.

5. Serentak dan global.

6. Meniadakan jarak dan waktu.

7. Dapat menyajikan peristiwa atau pendapat yang sedang terjadi, langsung atau orisinil dan tunda (rekaman).

8. Bahasa yang digunakan formal dan non formal (bahasa tutur).

9. Kalimat singkat, padat, jelas dan sederhana.

10. Tujuan akhir dari penyampaian pesan untuk menghibur, mendidik, kontrol sosial dan menghubungkan atau sebagai bahan informasi.

Darwanto ( 2007) mengemukakan dalam kaitannya terhadap peningkatan pengetahuan, suatu tayangan televisi hendaknya memperhatikan beberapa hal, antara lain :

\section{Frekuensi Menonton}

Melalui freksuensi menonton komunikan dapat dilihat dari pengaruh tayangan terhadap pengetahuan komunikan.

2. Waktu Penayangan

Apakah waktu penayangan suatu acara sudah tepat atau penayangan suatu acara sudah tepat sesuai dengan sasaran komunikan yang dituju.

3. Gaya Penampilan Pesan

Dalam menyampaikan pesan dari suatu tayangan, apakah host pembawa acara sudah cukup komunikatif dan menarik, sehingga dapat menghindari rasa jenuh pemirsanya dan juga memahami pesan yang disampaikan.

4. Pemahaman Pesan

Apakah komunikan dapat mengerti dan memahami setiap materi atau pesan yang disampaikan oleh suatu tayangan.

\section{Kelebihan dan Kekurangan Media} Televisi

Effendy (1993), televisi dianggap sebagai media yang mampu menyiarkan informasi secara memuaskan. Hal ini disebabkan faktor yang terdapat pada media massa televisi yaitu:

1. Immediacy, menyangkut pengertian langsung dan dekat, yakni peristiwa disiarkan oleh stasiun dapat dilihat dan didengar oleh pemirsa pada saat peristiwa tersebut berlangsung.

2. Realism mengandung makna kenyataan, ini berarti bahwa stasiun televisi menyiarkan informasinya audio visual dengan perantara mikrofon da kamera apa adanya sesuai kenyataan

Adapun kelemahannya antara lain :

1. Kecenderungan televisi untuk menempatkan khalaknya sebagai objek yang pasif sebagai sebagai penerima pesan.

2. Mendorong alih nilai dan pengetahuan yang tepat. Hal ini terjadi tanpa mempertimbangkan perbedaan tingkat perkembangan budaya dan peradaban yang ada di wilayah jangkauannya.

3. Sifatnya sangat terbuka dan menjadikannya sulit dikontrol dampak negatifnya.

4. Pergerakan teknologi penyiaran yang begitu cepat mendahului perkembangan masyarakat dan budaya khalayak. Hal ini pada gilirannya melahirkan pro kontra tentang implikasi cultural televisi.

5. Kecenderungan para pengelola televisi yang memanfaatkan kelebihan-kelebihan televisi dan lebih berorientasi pada pertimbangan komersial sehingga mengesampingkan faktor pendidikan. 


\section{Menonton Televisi}

Menonton televisi adalah suatu tindakan yang tidak lepas dari dorongan masing-masing individu untuk menikmati apa yang ditayangkan oleh televisi. Tindakan menonton televisi adalah kesadaran seseorang terhadap sesuatu yang masyarakat supaya dapat menjalani kehidupan secara baik dan positif. Berhubungan dengan dorongan yang ada dalam diri individu sehingga seseorang memusatkan perhatiannya terhadap acara yang ditayangkan ditelevisi dengan senang hati, serta dengan perasaan puas sehingga pemirsa dapat menikmati apa yang ditayangkan oleh televisi tersebut. Menonton berarti aktivitas melihat sesuatu dengan tingkat perhatian tertentu Danim (2004).

Penelitian sebelumnya yang dilakukan oleh Fadhilah (2011) menunjukan bahwa menonton televisi dapat diartikan aktifitas yang tidak hanya menyorotkan mata kea rah layar kaca melainkan penonton yang berfikir aktif untuk memilih, memakai dan juga menafsirkan dari tayangan- tayangan televisi tersebut. Intensitas menonton televisi merupakan tindakan atau keadaan seseorang yang menikmati tayangan di televisi dalam ukuran waktu tertentu dan menggambarkan seberapa sering serta memusatkan perhatiannya terhadap acara yang ditayangkan di televisi.

\section{Tayangan Religi}

Tayangan religi pada hakekatnya mengandung hal-hal yang berhubungan dengan keagamaan yang memperlihatkan hubungan manusia dengan Tuhan Yang Maha Esa harus mampu menyampaikan sisi positif yang sangat dominan dalam cerita sehingga tidak melenceng dari ajaran agama dan tidak mendapat respon negatif dari masyarakat apabila menampilkan sisi negatif yang berlebihan. Cerita-cerita yang bernuansa keagamaan ini menjadi alternatif penting untuk mengajak masyarakat mengingat kepada sang pencipta serta contoh-contoh perilaku menghormati orang yang lebih tua, kehidupan damai dengan saling tolong menolong sesama manusia.

\section{Unsur-Unsur Cerita atau Konten Film}

Sinetron memiliki konten film dan unsurunsurnya sebagai berikut :

1. Tema, merupakan pokok pikiran yang dipakai sebagai pengarang, pokok pikiran pengarang, ide pokok permasalahan.

2. Alur, adalah jalannya cerita, rangkaian peristiwa yang membentuk cerita dengan dasar hubungan sebab akibat. Pada umumnya terdapat tiga alur yang terdapat di sebuah sinetron yaitu :

a. Alur maju (progresif) adalah sebuah alur yang memiliki klimaks di akhir cerita dan merupakan jalinan atau rangkaian peristiwa dari masa kini ke masa lalu.

b. Alur mundur (regresif), disebut sebagai plot mundur adalah sebuah alur yang menceritakan tentang masa lampau yan memiliki klimaks di awal cerita dan merupakan jalinan atau rangkaian peristiwa dari masa lalu ke masa kini yang disusun tidak sesusai dengan urutan waktu atau kejadian dari awal sampai akhir cerita.

c. Alur Sorot balik (Flashback), adalah alur yang terjadi karena pengarang mendahulukan akhir cerita dan setelah itu kembali ke awal cerita. Pengarang bisa memulai cerita dari klimaks kemudian kemballi ke awal cerita menuju akhir.

d. Alur campuran (maju-mundur), merupakan alur yang diawali klimaks, kemudian melihat lagi masa lamau dan dilanjutkan sampai pada penyelesaian yang menceritakan banyak tokoh utama sehingga cerita yang satu belum selesai kembali ke awal untuk menceritakan tokoh yang lain.

\section{Latar}

Keterangan tempat, waktu dan suasana, tempat atau waktu terjadinya peristiwa. Latar dibagi menjadi tiga macam, diantaranya yaitu :

a. Latar tempat, yaitu lokasi atau bangunan fisik lain yang menjadi tempat terjadinya peristiwa-peristiwa dalam cerita. 
b. Latar waktu, yaitu waktu (masa) tertentu ketika peristiwa cerita itu terjadi.

c. Latar suasana, salah satu unsure intristrik yang berkaitan dengan keadaan psikologi yang timbul dengan sendirinya bersamaan dengn jalan cerita. Suatu cerita menjadi menarik karena berlangsung dalam suasana tertentu.

4. Tokoh atau Penokohan

Penokohan adalah lukisan watak pelaku, cara pengarang menggambarkan watak tokoh. Isttilah tokoh menunjukkan pada orangnya, pelaku cerita, sedangkan penokohan menunjukkan pada sikap kualitas pribadi tokoh.

Dilihat dari fungsi penampilan tokoh dalam cerita, tokoh dibedakan atas dua, yaitu:

a. Protagonist, adalah tokoh yang berfungsi memberikan simpati, empati, melibatkan diri secara emosional terhadap tokoh tersebut. Tokoh yang disikapi demikian disebut tokoh portagoist.

b. Antagonis, adalah tokoh yang berfungsi menimbulkan konflik dan berposisi dengan protagonist.

\section{Perilaku}

Perilaku adalah kecenderungan bertindak, berfikir, berpresepsi, dan merasa dalam menghadapi objek, ide, situasi, atau nilai. Sikap bukanlah perilaku, tetapi lebih merupakan kecenderungan untuk berperilaku dengan cara tertentu terhadap objek sikap. Objek sikap bisa berupa orang, benda tempat, gagasan, situasi, atau kelompok. Dengan demikian, pada kenyataannya tidak ada istilah sikap yang berdiri sendiri Sobur (2003). Pengaruh adalah kekuatan yang muncul dari suatu benda atau orang dan juga gejala dalam yang dapat memberikan perubahan terhadap apa-apa yang dapat memberikan perubahan (Surakhmad 1982).

\section{Efek Komunikasi Massa}

Rakhmat (2007), ada yang beranggapan bahwa efek hanyalah perubahan perilaku manusia setelah diterpa pesan media massa. Karena fokusnya pesan, maka efek haruslah berkaitan dengan pesan yang disampaikan media massa. Ada tiga dimensi efek komunikasi dalam Sayuti (2016) adalah kognitif, afektif dan konatif. Efek kognitif meliputi peningkatan kesadaran, belajar, dan tambahan pengetahuan. Efek afektif berhubungan dengan emosi, perasaan, dan attitude (sikap). Sedangkan efek behavioral berhubungan dengan perilaku dan niat untuk melakukan sesuatu menurut cara tertentu.

\section{METODE PENELITIAN}

Penelitian ini menggunakan metode survey dengan pendekatan kuantitatif. Penelitian ini juga menggunakan pendekatan deskriptif dengan tujuan untuk mendeskripsikan objek penelitian ataupun hasil dari penelitian. Adapun menurut Sugiyono (2011) adalah metode yang berfungsi untuk mendeskripsikan atau memberi gambaran terhadap objek yang diteliti melalui data atau sampel yang telah terkumpul sebagaimana adanya, tanpa melakukan analisis dan membuat kesimpulan yang berlaku umum. Penelitian dilakukan di Kp. Bojong Kiharib Rt.02 Rw.02 Desa Wates Jaya Kecamatan Cigombong Kabupaten Bogor. Waktu yang digunakan dalam kegiatan penelitian ini kurang lebih selama 3 bulan yaitu dari Januari 2018 sampai dengan Maret 2018. Penarikan sampel dilakukan dengan menggunakan teknik probability random sampling. penentuan sampel menggunakan rumus Slovin dengan tingkat kepercayaan (margin error) 90\%. Jumlah sampel penelitian sebanyak 78 orang masyarakat Kp. Bojong Kiharib Rt.02 Rw.02.Dalam penelitian ini skala pengukuran menggunakan Weight Mean Score yaitu dengan pembobotan nilai untuk skala 1-5.

Data penelitian dikumpulkan berdasarkan data primer dan data sekunder. Pengumpulan 
data primer dilakukan melalui penyebaran angket. Bentuk angket dalam penelitian ini adalah angket tertutup, adalah angket yang disajikan dalam bentuk sedemikian rupa sehingga responden diminta untuk memilih satu jawaban yang sesuai dengan karakterisik dirinya dengan cara memberikan tanda silang $(\mathrm{X})$ atau tanda centang $(\sqrt{ })$ pada masyarakat $\mathrm{Kp}$. Bojong Kiharib Rt.02 Rw.02. Sedangkan data sekunder dikumpulkan dari artikel, website, dokumen yang relevan. Data penelitian dianalisis dengan prosedur statistik menggunakan Skala Likert untuk melakukan pengukuran terhadap data ordinal. Skala pengukuran ini bertujuan untuk mengkualifikasi data dari reabilititasnya suatu peubah. Data ordinal tersebut kemudian akan dianalisis menggunakan rumus statistic koefisien korelasi tata jenjang Rank Spearman.

\section{HASIL DAN PEMBAHASAN}

\section{Karakteristik Responden dan Konten Tayangan FTV Kuasa Ilahi}

Responden yang dilihat dalam menonton film FTV Kuasa Ilahi dapat dilihat dari jenis kelamin, usia, pendidikan dan pekerjaan. Jumlah persentase laki-laki $35 \%$ dan perempuan $65 \%$. Usia masyarakat yang diteliti berkisar 10-49 tahun, sehingga ada kategori usia yang diantara 10-14 tahun 3\%, 15-19 tahun 3\%, 20-24 tahun 27\%, 25-29 tahun $19 \%, 30-34$ tahun 14\%, 35-39 tahun 9\%, 4044 tahun $11 \%$, 45-49 tahun 14\%. Dilihat dari identitas responden berdasarkan pekerjaan terdapat lima karakteristik responden yaitu ibu rumah tangga $15 \%$, karyawan $53 \%$, mahasiswa $15 \%$, wiraswasta $9 \%$, dan pelajar $7 \%$. Dalam penelitian ini terdapat $77 \%$ dengan pendidikan SMA/SMK, SMP $13 \%$, D3 $8 \%$, dan S1 $2 \%$. Adapun persepsi yang dimiliki oleh respoden terhadap konten FTV Kuasa Ilahi dinilai dalam bentuk persentase. Sebagaimana tampil dalam Tabel 1. 
Tabel 1 Persepsi Responden dan Konten FTV Kuasa Ilahi

\begin{tabular}{|c|c|c|c|}
\hline Peubah & Penilaian & Indikator & $\begin{array}{c}\text { Persentase } \\
(\%)\end{array}$ \\
\hline \multirow{10}{*}{$\begin{array}{c}\text { Karakteristik } \\
\text { Penonton }\end{array}$} & \multirow{3}{*}{ Usia } & Disukai & 76 \\
\hline & & Dikenal Semua Umur & 75 \\
\hline & & Cocok Segala Umur & 81 \\
\hline & \multirow{4}{*}{ Pendidikan } & Hiburan & 77 \\
\hline & & Dakwah & 81 \\
\hline & & Edukasi & 88 \\
\hline & & Toleransi Beragama & 76 \\
\hline & \multirow{3}{*}{$\begin{array}{l}\text { Frekuensi } \\
\text { Menonton }\end{array}$} & Ketepatan waktu & 78 \\
\hline & & Durasi menonton & 80 \\
\hline & & Intensitas Menonton & 75 \\
\hline \multirow{8}{*}{ Konten Film } & \multirow{3}{*}{ Alur Cerita } & Daya tarik & 81 \\
\hline & & Alur yang imbang & 65 \\
\hline & & Makna yang baik & 65 \\
\hline & \multirow{2}{*}{$\begin{array}{c}\text { Karakter } \\
\text { Penokohan }\end{array}$} & Ketokohan Antagonis & 84 \\
\hline & & Ketokohan Protagonis & 75 \\
\hline & \multirow{3}{*}{ Nilai Budaya } & Pesan Moral & 84 \\
\hline & & Pesan Ilahiah & 80 \\
\hline & & $\begin{array}{l}\text { Pesan hubungan } \\
\text { manusia }\end{array}$ & 79 \\
\hline
\end{tabular}

Berdasakan Tabel 1 penilaian responden mengenai usia indikator tayangan kuasa ilahi disukai, dikenal semua umur dan cocok segala umur memiliki nilai persentase rata-rata diatas 77. Hal ini mengandung pengertian bahwa masyarakat menyatakan tayangan FTV kuasa ilahi cocok untuk ditonton oleh semua umur karena setelah menonton tayangan tersebut mereka dapat membedakan mana yang patut ditiru dan tidak boleh ditiru. Setelah itu, penilaian responden mengenai tayangan kuasa ilahi terdapat unsur pendidikan dengan indikator hiburan, dakwah, edukasi dan toleransi beragama memiliki nilai persentase rata-rata diatas 80. Hal ini mengandung pengertian bahwa responden menyatakan tayangan FTV kuasa ilahi terdapat unsur pendidikan, sebab setiap adegannya menggambarkan atau mencontohkan perilaku yang baik, terdapat ayat suci Al-Qur'an dan hadis yang dapat mengubah penonton menjadi lebih baik. Selanjutnya, dapat dijelaskan bahwa penilaian responden mengenai frekuensi menonton dengan indikator ketepatan waktu, duras menonton, intensitas menonton memiliki nilai persentase rata-rata 77 . Hal ini mengandung arti bahwa responden sering menonton tayangan FTV tersebut, dan setelah menonton penonton menjadi tahu mana perilaku yang baik dan yang buruk.

Selanjutnya, dapat dijelaskan bahwa penilaian responden mengenai alur cerita dengan indikator daya tarik, alur yang imbang, makna yang maik memiliki nilai persentase rata-rata diatas 70 . Hal ini mengandung arti bahwa tayangan FTV kuasa ilahi ceritanya menarik dan membuat para penonton untuk tetap berbuat baik kaerna takut akan azab Allah SWT. Responden menilai mengenai karakter penokohan dalam indikator ketokohan antagonis dan protagonis memiliki nilai persentase rata-rata 79 . Hal ini mengandung arti penonton setuju bahwa ditayangan FTV kuasa ilahi terdapat tokoh protagonis (baik) dan 
antagonis (jahat) yang membuat suasa haru, emosi karena kesabarannya yang telah melewati ujian dari Allah SWT. Dan selanjutnya dapat dijelaskan bahwa penilaian responden mengenai nilai budaya dalam indikator pesan moral, pesan ilahiah dan hubungan sesama manusia memiliki nilai persentase rata-rata 81 . Hal ini mengandung arti bahwa penonton setuju bahwa di tayangan FTV
Kuasa Ilahi terdapat pesan moral, yang membuat mereka mempunyai sikap merenung supaya menjadi mahluk yang lebih baik.

Sajian karakteristik penonton terhadap konten film memiliki nilai persepsi yang memiliki selera menonton yang cukup baik dalam menilai alur cerita, karakter serta nilai budaya. Hal ini ditayangkan pada Tabel 2.

Tabel 2 Persepsi Karakteristik Penonton Terhadap Konten Film

\begin{tabular}{clccc}
\hline \multirow{2}{*}{$\begin{array}{c}\text { Peubah } \\
\text { Ksia }\end{array}$} & Alur Cerita & $\begin{array}{c}\text { Konten Film (\%) } \\
\text { Karakter } \\
\text { Penokohan }\end{array}$ & $\begin{array}{c}\text { Nilai } \\
\text { Budaya }\end{array}$ \\
\cline { 2 - 5 } $\begin{array}{c}\text { Karaktersitik } \\
\text { Penonton }\end{array}$ & Pendidikan & 77 & 79 & 79 \\
\cline { 2 - 5 } & $\begin{array}{l}\text { Frekuensi } \\
\text { Menonton }\end{array}$ & 77 & 81 & 81 \\
\cline { 2 - 5 } & Rata-rata & 76 & 79 & 79 \\
\hline
\end{tabular}

Tabel 2 responden menunjukkan mayoritas memiliki pemahaman yang baik terhadap konten yang terdapat ditayangan FTV Kuasa Ilahi, hal ini dapat dilihat dari hasil dimana masing-masing persentase memiliki nilai persentase diatas rata-rata 76 sampai 80 , hanya beberapa bagian saja yang memiliki nilai dibawah rata-rata antara lain frekuensi menonton. Dalam hal ini masyarakat cukup memahami, mengetahui, dari apa yang ditampilkan dan ditayangkan dalam FTV Kuasa Ilahi.

Tabel 3 Perilaku Responden Terhadap Tayangan FTV

\begin{tabular}{|c|c|c|c|}
\hline Peubah & Dimensi & Indikator & Persentase $(\%)$ \\
\hline \multirow{12}{*}{$\begin{array}{l}\text { Perilaku } \\
\text { (4,15: } \\
\text { Sangat } \\
\text { tinggi) }\end{array}$} & \multirow{2}{*}{$\begin{array}{c}\text { Kognitif } \\
(4,34 \text { : sangat } \\
\text { Tinggi }) \\
\end{array}$} & Nilai Positif & 82 \\
\hline & & Efek Positif & 91 \\
\hline & \multirow{4}{*}{$\begin{array}{c}\text { Afektif } \\
(3,95: \text { Tinggi })\end{array}$} & Pesona Cerita & 77 \\
\hline & & Emosi & 88 \\
\hline & & Faktual & 76 \\
\hline & & Edukasi & 76 \\
\hline & \multirow{5}{*}{$\begin{array}{c}\text { Konatif } \\
(4,16: \text { Sangat } \\
\text { Tinggi })\end{array}$} & Spiritual & 84 \\
\hline & & Kesenangan & 88 \\
\hline & & Disiplin & 72 \\
\hline & & Efek mononton & 88 \\
\hline & & Peniruan & 84 \\
\hline & Rata-rata & & 82 \\
\hline
\end{tabular}


Adapun penilaian perilaku menonton tersaji dalam Tabel 3 responden menunjukkan mayoritas memiliki pemahaman yang baik dalam menonton televisi, hal ini dapat dilihat dari hasil perilaku menonton sebesar 4,15 (sangat tinggi) dimana masing-masing persentase memiliki nilai persentase diatas ratarata 82 hanya beberapa bagian saja yang memiliki nilai di bawah rerata antara lain pesona cerita, faktual, edukasi, kedisiplinan dalam menonton. Setiap tayangan dianggap oleh responden memiliki alur yang menarik untuk disaksikan. Masyarakat sangat baik dalam mendapat penerapan dari aspek kognitif, afektif dan konatif atau perilaku yaitu masyarakat cukup memahami, mengetahui apa yang ditampilkan dan ditayangkan dalam FTV Kuasa Ilahi di MNCTV.

\section{Pengaruh Konten Tayangan FTV Kuasa Ilahi Terhadap Perilaku Menonton}

Salah satu elemen terpenting dalam membentuk sebuah karya sastra adalah plot cerita. Dalam analisis cerita, plot sering disebut dengan istilah alur. Plot atau alur sering diartikan sebagai keseluruhan rangkaian peristiwa yang terdapat dalam cerita. Dalam hal ini peneliti memasukkan kategori plot dalam istilah konten tayangan. Adapun pengaruh Konten Tayangan Terhadap Perilaku Menonton FTV Kuasa Ilahi tersaji dalam Tabel 5.

Tabel 5. Pengaruh Konten Tayangan Terhadap Perilaku Menonton FTV

(Uji Pearson Correlation Pada Taraf Kepercayaan 99\%) N- 78

\begin{tabular}{lcc}
\hline & Konten Tayangan & Sig (2-taile) \\
\cline { 2 - 3 } Perilaku Menonton & $.902^{* *}$ & .000 \\
\hline
\end{tabular}

Tabel 4, analisis koefisien Pearson Correlation antara menonton tayangan FTV Kuasa Ilahi terhadap perilaku masyarakat di dapat koefisien 0,902**. Maka menonton tayangan FTV Kuasa Ilahi terhadap perilaku masyarakat adalah sangat baik. Oleh karena itu untuk menguji diterima atau ditolaknya hipotesis maka dilakukan pengujian signifikan koefisien korelasi dengan rumus $t$-test. Hasil perhitungan diperoleh nilai $t_{\text {hitung }}$ hasil penelitian sebesar 18,213. Kemudian nilai $t_{\text {hitung }}$ dibandingkan dengan $t_{\text {tabel }}$ distribusi $t$ dengan taraf signifikan (a) $=0,05$ dengan derajat kebebasan $(\mathrm{df})=\mathrm{n}-2$. Maka nilai $t_{\text {tabel }}$ adalah 0,667. Hal tersebut menunjukan bahwa ternyata $t_{\text {hitung }}>t_{\text {tabel }}$. Dengan demikian terdapat pengaruh yang signifikan pada menonton tayangan FTV terhadap perilaku masyarakat. Hal tersebut mengidentifikasikan bahwa hipotesis yang diajukan diterima dan diterima kebenarannya. Artinya, terdapat pengaruh yang signifikan pada menonton tayangan FTV kuasa ilahi terhadap perilaku masyarakat. Livia (2014), menunjukan bahwa setelah penonton menonton acara@Show_imah, dapat dilihat dari komponen perilaku atau komponen konatif dalam struktur sikap menunjukkan bagaimana perilaku atau kecenderungan berperilakuyang ada dalam diri seseorang berkaitan dengan objek penonton yang rutin dari acara @Show_imah. Komponen perilaku berisi tendeksi atau kencederungan untuk bertindak atau untuk bereaksi terhadap sesuatu dengan cara-cara tertentu. Dan hal ini menunjukan bahwa sebagian besar penonton acara @Show_imah di Trans Tv memili sikap positif dan sebagian kecil menunjukan sikap yang negatif. Senada dengan penelitian Bahari et al. (2017) menunjukkan ada kecenderungan seorang remaja meniru apa yang ditampilkan di media terlebih dalam sebuah tayangan opera sabun atau sering disebut sebagai sinteron. 
Tayangan ini memiliki nilai magis yang mampu menyerap pemuda untuk mengikuti alur cerita dalam kehidupan nyata mereka. Sehingga perlu menjadi kontrol para orang tua dalam menyaring tayangan-tayangan yang tidak mendidik dan mencoba memilih tayangan buat kalangan remaja yang meranjak dewasa dengan tayangan yang bernilai positif.

\section{KESIMPULAN DAN SARAN}

\section{Kesimpulan}

1. Karakteristik responden dilihat dari sisi usia mayoritas berada pada usia (20-24 tahun), pendidikan SMA $78 \%$, frekuensi menonton $80 \%$ kategori sering, dengan tampilan konten dilihat dari sisi alur cerita, karakter penokohan dan nilai budaya sudah sesuai dengan harapan penonton.
2. Perilaku responden terhadap konten tayangan sinetron berpengaruh nyata dengan kriteria penilaian pada aspek kognitif (4,34: sangat tinggi), afektif $(3,95$ : tinggi), dan konatif (4,16 : sangat tinggi) dengan pengaruh 0,902 (sangat nyata) pada taraf $99 \%$ tingkat kepercayaan.

\section{Saran}

Berdasarkan hasil penelitian maka dapat disarankan sebagai berikut:

1. Sebaiknya orang tua harus tetap mengawasi anak ketika menonton tayangan tersebut karena yang mendominasi menonton adalah remaja yang baru tumbuh berkembang.
2. Perlu dilakukan penelitian dengan pendekatan keilmuan psikologi komunikasi untuk melihat seberapa besar peniruan yang diterapkan oleh penonton terhadap tayangan yang ditonton.

\section{DAFTAR PUSTAKA}

Bahari DW, Ratnamulyani IA, Kusumadinata AA. 2017. Pengaruh Tayangan Sinetron Anak Jalanan Terhadap Perilaku Anak. Jurnal Komunikatio 3(1): 1-8.

Darwanto. 2007. Televisi Sebagai Media Pendidikan. Yogyakarta (ID) : Pustaka Pelajar.
Danim S. 2004. Motivasi Kepemimpinan dan Efektifitas Kelompok. Bandung (ID) : Penerbit Rineka Cipta.

Desti. S. 2005. Dampak Tayangan Film di Televisi Terhadap Perilaku Anak. Jurnal Komunikologi 2 (1) : 1-7.

Effend OU. 1993. Televisi Siaran: Teori dan Praktek. Bandung (ID) : Mandar Maju. 
Effend OU. 2003. Ilmu, Teori dan Filsafat Komunikasi. Bandung: PT. Citra Aditya Bakti.

Livia P. 2014. Sikap Masyarakat Surabaya Terhadap Tayangan Talkshow @Show_Imah di Trans Tv. Jurnal EKomunikasi 2 (1): 1-10.

Rakhmat J. 2007. Metode Penelitian Komunikasi. Bandung : PT. Remaja Rosdakarya.

Rinawati R. 2002. Pengaruh Sinetron Terhadap Sikap Ibu-Ibu Mengenai Peran Ganda Wanita. Jurnal Mediator 3 (1) : 109118.
Sayuti.2016. Efek Tayangan Stand Up Comedy Metro Tv Terhadap Perilaku Penonton Usia Muda di Loa Junan Kutai Kartanegara. EJurnal Ilmu Komunikasi 4 (3) :474-487.

Surakhmad W.1982. Pengantar Interaksi Belajar Mengajar, Dasar dan Teknik Metodolohi Pengajaran. Bandung : Tarsito.

Sobur A. 2003. Psikologi Umum. Bandung (ID): Pustaka Setia.

Sugiyono. 2011. Metode Penelitian Kuantitatif, Kualitatif, $R \& D$. Bandung (ID): Alfabeta.

Wahyudi JB. 1996. Komunikasi Jurnalistik dalam Wawan Kusnadi, Komunikasi Massa Sebuah Analisis Media Televisi”. Jakarta (ID) : PT. Rineka Cipta. 